\title{
OVERVIEW OF THE FORMATION AND DEVELOPMENT OF A HUMAN POTENTIAL MANAGEMENT SYSTEM
}

The purpose of the article is to substantiate the basic principles and mechanisms for improving the effectiveness of the personnel management system (in the construction industry).

Methodology and methods. The theoretical and methodological basis of the study is the theoretical and practical studies of domestic and foreign economists and specialists, scientific papers, as well as materials from national, regional and international scientific conferences. The study used a comparative analysis of various scientific theories and concepts proposed to improve the management system.

Results. The article discusses the theoretical and methodological foundations of managing the construction industry on the basis of non-traditional, effective and modern technological foundations, determines the ways of their application and improvement in the construction sector management system, which is one of the key sectors of the economy of the Republic of Azerbaijan, and gives practical suggestions for solving the data problems.

It is noted that the effective use of human resources at an enterprise is a multifaceted socio-economic problem that affects all aspects of the enterprise's life. In other words, acquiring resources, an organization seeks to effectively use them to achieve its goals. Here efficiency for the organization must be ensured in terms of the volume of these resources, methods of their use, space, time and duration of interaction, the optimal ratio of resources used.

Conclusions. Author summarizes the questions raised in the study and shows that increasing the efficiency of enterprise management is possible thanks to a systematic analysis and application of various points of view presented in local, foreign, specialized and scientific literature. It is noted that for this, the managers of the enterprise should pay attention to pressing issues of the effective use of human resources in the future.

Key words: human resources, management, efficiency, construction industry, socio-economic problems. economic system, labor force, labor market, organization, corporate spirit, organizational culture.

JEL Classification: O15, L74, P00, J21, J40, M14.

\section{Rashad RAFIGLI,}

PhD Student at the Department of Socio-Economic Problems of Living Standards

Institute of Economics of the National Academy of Sciences of Azerbaijan matlabm@yandex.ru

orcid.org/0000-0001-5211-8359

\section{Introduction}

In connection with non-traditional, effective and modern management technologies in the construction industry, studying its theoretical and methodological foundations and determining the ways of its application, improving the construction sector, one of the main sectors of the economy in the Republic of Azerbaijan, and thereby eliminating many socio-economic problems are an important step.

Clarification of the basic concepts of the development of the human resource management system is possible on the basis of a systematic generalization of local, foreign, special and scientific literature. In the short term, problems in the field of human resource management, organization of issues related to increasing the efficiency of their use in the labor process on the basis of modern principles and mechanisms should be in the center of attention of enterprise managers.

The effective use of human resources at an enterprise is a multifaceted socio-economic problem that affects all aspects of the enterprise's life. By acquiring resources, an organization seeks to effectively use them to achieve its goals. Here efficiency for the organization must be ensured in terms of the volume of these resources, methods of their use, space, time and duration of 
interaction, the optimal ratio of resources used. Human resource management is a fundamental component of the management of any organization.

In the science of managing the economic activity of personnel, questions arise that increase labor productivity as a factor of production. These characteristics are mainly the result of the close relationship between the job and the person doing it. Doing work means attracting, for example, with the personalities of specific people in the enterprise.

As a rule, in order to obtain the final product, a large number of people work at the enterprise in the condition of the division of labor. As a result, there is a certain imbalance, on the one hand, between social problems, as well as between qualifications and productivity, and on the other, between the motivational boundaries of labor force rotation. The investments expected from people working at the enterprise depend on their attitude to the enterprise, on the goals and objectives (identification), on the assessment of the compliance of the desired and actual investments in production with the incentive. This increases the importance of the problem of incentives and motivation.

Therefore, the interests of the organization (companies, corporations) as an economic system are realized not only by the acquisition of labor in the labor market, but also by their use within the organization. These interests include bringing the acquired employees to the required quality and structural parameters within the company, instilling in them a corporate spirit and organizational culture. This shows a new trend in production management.

Purpose of the article is substantiation of the basic principles and mechanisms for increasing the efficiency of the human resource management system (in construction).

\section{Methodology and methods}

The theoretical and methodological basis of the research is theoretical and practical training of domestic and foreign economists and specialists, scientific works, as well as materials of national, regional and international scientific conferences. The study used a comparative analysis of various scientific theories and concepts proposed to improve the management system.

As a novelty, the article examines the theoretical and methodological foundations of management of the construction industry on the basis of non-traditional, effective and modern technological foundations, determines the ways of their application and improvement in the management system of the construction sector, which is one of the key sectors of the economy of the Republic of Azerbaijan, and gives practical proposals for solving data problems.

\section{Review of the latest publications on this topic}

Production efficiency is expressed as the ratio of the result (influence) of production to labor costs. Therefore, as a factor of production efficiency, on the one hand, there are production costs, and on the other, the place of labor in the volume of the gross product, that is, the result of production in the form of income (Playtner, 2002: 76).

Each type of expenses corresponds to a certain indicator that measures the level and dynamics of the efficiency of reserve consumption (labor productivity, capital intensity, material consumption). The effective use of human resources reflects part of the overall efficiency due to the economy and productivity (effect) of living labor (Odegov, Zhuravlev, 1997: 87).

Human resource management is a classic activity that involves recruiting appropriate personnel and rewarding their training, skills and abilities. Nevertheless, this also implies bringing the position to the staff by the management, justifying the work done, meeting the labor needs of workers, providing assistance in solving their problems (Travin et al., 2015: 23).

Thus, the effectiveness of the use of human resources is determined by the degree of people's participation in achieving their goals, eliminating various negative consequences and reducing certain expenses of the organization. The effectiveness of management is measured by the balance of specific features, such as the achievement of certain goals, the effective use of skills and abilities of personnel, the protection of highly qualified and profitable employees (Podvoyskiy, 1992: 31).

The main motive of today's management system is that rational use of labor potential is at the heart of improving management methods and systems. In modern conditions, along with financial and production capital, knowledge, skills, labor competencies, efficiency, initiative, value-motivational spheres (i. e., the main accumulated potential of an employee) of employees of any enterprise become the most important strategic resources (Playtner, 2002). 
Enterprise management is divided into 4 areas that define its various structural aspects: product management, market management, financial management and personnel management. For a long time, the concept of "human resource management" did not exist in management practice. However, the management system of each organization has always had a functional subsystem of team management and social development, but the main work on personnel management was carried out by managers. In modern market conditions, there is a transition from hierarchical management, a rigid system of administrative influence, unlimited power to relations based on socio-economic methods (Grekhem, Bennett, 2003: 101).

Russian researcher I.I. Moiseeva in her article "Evaluation of the effectiveness of good structural divisions of commercial organizations" studied the problems of assessing the effectiveness of the structural divisions of the organization. Today the widespread traditional systematic approach to assessing the effectiveness of a commercial organization, based on a resource approach and profitability indicators, is criticized. It is said that this makes it possible to adequately assess performance in only a short period of time. The use of a financial model in assessing the effectiveness of activities is based on the market type of economic thinking, therefore, all parameters that affect the efficiency of an enterprise are among the factors that determine its internal environment. The traditional system of financial indicators does not provide real information about the current situation. Improving the activities of organizational units at different levels, attempts to minimize costs, increasing the level of professionalism are the most important tools for increasing the overall efficiency of entrepreneurial activity (Moiseeva, 2013).

Other Russian researchers A.E. Petrovykh and E.G. Aksenova in the article "Economic efficiency of urban areas development" talk about the ratio of costs for all factors involved in the production process. It is noted that the country's economy should always support the formation and strengthening of market mechanisms in many industries and spheres of activity (Aksenova, Petrovykh, 2015).

Other researchers O.I. Tolmacheva and M.V. Beznoshenko in a joint article "Features of the organization and creation of cost accounting systems at enterprises producing construction products" consider the issues of reliable cost accounting in the construction industry and the creation of an analytical support system for this, describe production characteristics enterprises for the production of building materials (Tolmacheva, Beznoshchenko, 2018).

Ufa researchers A.R. Mirzoeva and M.Kh. Shogenova in a joint article "Assessment of the economic efficiency of the integrated use of raw materials", examining the features of the formation and evaluation of the effectiveness of the integrated use of raw materials, note that they have developed a methodology for assessing the economic efficiency of using mining waste as construction materials (Mirzoeva, Shogenova, 2013).

Other researchers conducting research in this area, N.S. Samofeev and V.F. Kovalev, in their articles "Increasing the competitiveness and economic efficiency of construction projects of low-rise residential complexes in Ufa", noting that the construction industry plays a leading role in the economic growth of the national industry and the economy of the country as a whole, they write that the use of innovative, new technical and technological means at different stages of the production of construction products, necessary to create favorable conditions for the development of the construction industry, has great potential (Samofeev, Kovalev, 2017).

\section{Presentation of the main material}

There are a number of scientific approaches to working with people. Given the variety of existing approaches to this problem, the main general trends can be identified: the formation of methods and procedures for the selection of personnel, the development of scientific criteria, their assessment, a scientific approach to the analysis of the needs of management personnel, the justification of personnel decisions, the expansion of their potential, the compliance of management decisions with the main elements. personnel policy. Changes in the economy have led to changes in organizational structures and human resource management practices. There was a transition from the formation of a personnel policy to the development of a personnel management system. A relatively new function called "human resource management" was created, which replaced the practice and concept of the "personnel department" (Schein, 1985: 50). The evolution of concepts in the human resource management system is shown in table 1.

According to Edgar Schein, the essence of human resource management is to evaluate people as an asset of the company in the competitive struggle to develop and motivate people along with other resources to achieve the strategic goals of the organization.

Today, of course, the goal of human resource management is to create the impression of efficiently shaping and using human resources within an organization. 
Table 1

Evolution of human resource management concepts and the role of a person in an organization

\begin{tabular}{|c|c|}
\hline Human Model & Human Role \\
\hline "Economic man" & Tool, factor of production \\
\hline "Psychological person" & Production factor, resources of the organization \\
\hline "Human - administrator" & Main resource \\
\hline "Social person" & Main subject \\
\hline "Free man" & \\
\hline
\end{tabular}

At the same time, there are parties that support a broader understanding of personnel issues. For example, V. French in his book "The process of personnel management: human resource management" noted that "personnel management is considered as a dynamic aspect of the overall management process, which is part of the entire structure of the enterprise" (French, 1982: 46).

It should be noted that the concept of "personnel management" as the main means for achieving organizational goals has long been developed. In the work of O. Tead and H.C. Metcalf "Human resource management: its basic principles and practice" published in 1920 and known as a classic textbook on human resources, it is noted that "personnel management is planning, control, management and coordination of any organization, which assumes at least human efforts and difficulties (unanimity of cooperation and real concern for the real well-being of all members of the organization) for specific purposes" (Tead, Metcalf, 1926: 2).

The roots of human resource management go deep into the history of human society. Analyzing the development process of the human resource management function, one can trace the most significant stages in the evolution of theoretical approaches to personnel management at the enterprise.

At the beginning of the industrial era, the organization of personnel was practically created as a military-command system: a rigid hierarchy of a pyramidal type, a strict division of functions between commanders and executive soldiers, and disciplinarity with intermediaries to carry out orders from above.

The roots of human resource management go deep into the history of human society. Analyzing the development process of the human resource management function, one can trace the most significant stages in the evolution of theoretical approaches to personnel management at the enterprise.

At the beginning of the industrial era, the organization of personnel was practically created as a military-command system: a rigid hierarchy of a pyramidal type, a strict division of functions between commanders and executive soldiers, and disciplinarity with intermediaries to carry out orders from above.

This can be explained as a model, a model of military command, in front of the heads of large enterprises with a large workforce. As a result of the industrial revolution that took place after 1916, certain changes took place in the nature of labor - the specialized labor of professionals was replaced by the mechanical and meaningless labor of the proletariat.

In the 20-30s of the XX century, significant changes began to occur in the management of human resources in the industry of developed countries. These changes were due to three main factors: the emergence and spread of methods of "scientific organization of labor (NOT)", more precisely "scientific management"; development of the trade union movement; was characterized by constant state interference in relations between workers and employers. The foundations of the theory of "scientific management" were first presented in the book "Management - Science and Art", co-authored by Frederic Taylor (USA) and Henri Fayol (France) (Teylor, 2010). However, these ideas were later noted in the works of other scientists. This theory created a "quiet revolution" in the formation of the leadership of the organization, and in particular in the management of human resources. With the spread of the idea of the scientific organization of labor at many enterprises, a new profession began to arise - engineers engaged in the study and optimization of methods of working with people (Mayo, 1933: 58).

In developed countries, in response to the growing gap between social strata of society and the trend of intensive growth of productive forces, the authorities of these countries began to actively intervene in the regulation of relations between workers and employers. Government intervention has led to the creation of social insurance systems, unemployment benefits, minimum wages and the normalization or reduction of working hours. In some countries, special government agencies have been established to monitor working conditions and protect the interests of workers. As a result of changes in the legislative system, companies began to need specialists capable of working professionally to provide supervision in the field of labor 
legislation. State bodies and enterprises responsible for labor relations began to create special bodies dealing with the regulation of labor relations, labor protection standards and other legislative issues. These bodies were called personnel departments. In the 1920s and 1930s, human resources departments established in enterprises played the role of a subdivision, mainly carrying out regular "office work", and their functions began to serve as technical assistance for management.

During World War II, the personnel departments of military and non-military industrial enterprises (USA, Great Britain) played a major role in solving some issues. This included hiring and training hundreds of thousands of new workers in all trades to replace conscripts.

Since then, the selection and training of the necessary personnel in various professions and specialties has become the most important area of activity of human resources management departments.

In the late 1920s, American scientists E. Mayo and F. Roeslisberger first proposed the concept of "human relations". It was based on the idea, independent of the methods of organizing labor productivity, more dependent on managers who show an adequate attitude towards performers, that is, on the human factor (Roethlisberger, 1941; McGregor, 1960).

Although World War II distracted the attention of entrepreneurs from the idea of "human relations" for a while, interest in the human factor rekindled in the 1950s. In 1960, David McGregor published The Human Face of the Enterprise, in which he criticized the theory of the scientific organization of labor. The teachings of McGregor and other theorists who developed Mayon's views changed the way leaders view management and learning. In the 1960s and 1970s, American business schools incorporated human resources guidelines into their curricula. New leaders have entered the economy. They, along with finance and procurement in management practice, began to use the function of human resource management (Starobinskiy, 2000).

In the 1970s in the United States and in the 1980s in Western Europe, HR departments began to be replaced by HR departments. As a result, the concept of a humane approach to people management was developed, and these departments were expanded in areas such as planning and career development of employees, normalization of work, involvement of employees in general management.

In the 1980s and 1990s, the accelerated widespread use of information and robotics technologies in manufacturing was accompanied by globalization of markets and a significant increase in competition. Enterprises began to make every effort to ensure the impeccable quality of their products and services. This, in turn, required increased attention to all elements of the production process. A more flexible application of work organization, which provides strong motivation for work, has expanded the wide range of individual employee initiative that adds value to rational performance. In other words, there is an urgent need for a flexible management system to increase the flexibility of the work process, flexible wage policies and to solve various problems of the work process.

In the recent past, competition has focused on areas such as technological progress, technology cycles, organizational structures, marketing and post-sale situations.

Over the past 20-30 years, foreign business has radically changed its approach to "human resources" and commercial success. The motto "People are our main resource" is found in almost every effective company. This is not just a slogan, but the result of a huge technique, means and methods that have been tested over the years in the approach to personnel.

Here, to determine the role of people and the content of their participation in the management of the enterprise, the following can be noted. In the theory of management, a number of terms are used that reflect the participation of people in social production: labor resources, human resources, the human factor, labor force, human resource management, labor potential, etc. resources and ways to solve it (Guseynova, 2013: 13).

The concept of human resource management is a product of a theory that confirms the scientific basis of bureaucratic organizations in the concept of management developed since the 1930s. Here, a person was considered as a means playing a formal role or function in the production process, and management was carried out through administrative mechanisms (principles, methods, functions).

The concept of human resource management began to consider a person not as a duty, but as an irreplaceable resource, that is, in the unity of the 3 main components of an element of social organization (labor function, social relations, employee position). This concept has been used in a fragmentary form in Azerbaijan for more than 30 years and was disseminated as "activation of the human factor" in the years of "reconstruction", reflected in the works of such researchers as T. Guliyev et al. (Guseynova, 2013). 


\section{Conclusions}

The concept of "human factor" reflects the status of the individual in modern society, which to a certain extent is proportional to the technical and economic factors of production. In this case, labor is presented as the main factor of production, which is replaced by capital, that is, labor productivity can change both with and without conditions. Here, labor costs largely depend on the transactions being made.

The concept of "human factor" began to be replaced by the scientific term "labor potential" as a movement from complexity to simplicity, from abstraction to concreteness, clarity, and difference. Today economists and sociologists use this term to define the term "human factor" both at the level of society and within individual production groups. The general consensus is that "labor potential" should be presented in the form of a multilateral process that expresses continuous latent opportunities in the dynamics of human factors assessment.

The term "potential" was introduced 20-25 years ago. From an etymological point of view, it means "hidden possibilities, strength, power". A broad interpretation of the concept of "potential" is to consider it as "a source of opportunities, a means to start, a solution to a problem or reserve means to achieve a certain goal; the possibility of an individual, society, state in a certain area". Thus, the terms "potential" and "potential" mean that opportunities and abilities in any relevant area of life have not yet been determined (any person, the original work collective, society as a whole).

Defining this category, the concepts of "potential" and "resources" cannot be opposed. Potential (economic, production, labor) is a general aggregate characteristic of resources associated with space and time.

\section{References:}

1. Playtner, Kh.Y. (2002). Znachenie "chelovecheskogo faktora" dlya malykh i srednikh predpriyatiy [The importance of the "human factor" for small and medium-sized enterprises]. Problemy teorii i praktiki upravleniya - Problems of theory and practice of management, no. 2, pp. 71-76 [in Russian].

2. Odegov, Yu.G., Zhuravlev, P.V. (1997). Upravlenie personalom: uchebnik [Personnel management: textbook]. Moscow: Finstatinform, 877 p. [in Russian].

3. Travin, V.V., Maguram, M.I., Kurbatova, M.B. (2015). Upravlenie chelovecheskimi resursami: modul' IV [Human Resource Management: Module IV]. Moscow: Delo, 158 p. [in Russian].

4. Podvoyskiy, G.L. (ed.) (1992). Upravlenie - eto nauka i iskusstvo: sbornik [Management is science and art: collection]. Moscow: Respublika, 349 p. [in Russian].

5. Grekhem, G.T., Bennett, R. (2003). Upravlenie chelovecheskimi resursami: uchebnoe posobie [Human resource management: study guide] / transl. from English T.Yu. Bazarova, B.L. Eremina. Moscow: YuNITI-DANA, 598 p. [in Russian].

6. Moiseeva, I.I. (2013). Otsenka effektivnosti deyatel'nosti otdel'nykh strukturnykh podrazdeleniy kommercheskoy organizatsii [Evaluation of the performance of individual structural divisions of a commercial organization]. Sotsial'no-ekonomicheskie yavleniya i protsessy - Socio-economic phenomena and processes, no. 12(58), pp. 90-96 [in Russian].

7. Aksenova, E.G., Petrovykh, A.E. (2015). Ekonomicheskaya effektivnost' ot razvitiya gorodskikh territoriy [Economic efficiency from the development of urban areas]. Ekonomika i ekologiya territorial'nykh obrazovaniy - Economy and ecology of territorial entities, no. 1, pp. 3 [in Russian].

8. Tolmacheva, O.I., Beznoshchenko, M.V. (2018). Osobennosti organizatsii i postroeniya sistemy ucheta zatrat na predpriyatiyakh, proizvodyashchikh stroitel'nye materialy [Features of the organization and construction of a cost accounting system at enterprises producing building materials]. Ekonomika i biznes: teoriya i praktika - Economics and business: theory and practice, no. 12, issue 2, pp. 141-144 [in Russian].

9. Mirzoeva, A.R., Shogenova, M.Kh. (2013). Otsenka ekonomicheskoy effektivnosti kompleksnogo ispol'zovaniya syr'ya [Assessment of the economic efficiency of the complex use of raw materials]. Ekonomicheskiy analiz: teoriya i praktika - Economic analysis: theory and practice, no. 33(336), pp. 51-60 [in Russian].

10. Samofeev, N.S., Kovalev, V.F. (2017). Povyshenie konkurentosposobnosti i ekonomicheskoy effektivnosti proektov stroitel'stva maloetazhnykh zhilykh kompleksov $v$ g. Ufa [Increasing the competitiveness and economic efficiency of projects for the construction of low-rise residential complexes in Ufa]. Internet-zhurnal "Naukovedenie" - Internet Journal "Science of Science", vol. 9, no. 1. Retrieved from: https://naukovedenie.ru/PDF/97EVN117.pdf [in Russian].

11. Schein, E.H. (1985). Organizational Culture and Leadership. San Francisco: Jossey Bass Publishers, 358 p. [in English]. 
12. French, W.L. (1982). Personnel Management Process: Human Resources Administration and Development. Boston: Houghton Mifflin Co, 684 p. [in English].

13. Tead, O., Metcalf, H.C. (1926). Personnel administration: its principles and practice. New York: McGraw-Hill Book Co., 543 p. [in English].

14. Teylor, F. (2010). Printsipy nauchnogo menedzhmenta. Chast' I. Predposylki nauchnogo upravleniya [Principles of Scientific Management. Part I. Prerequisites for scientific management]. Tsentr gumanitarnykh tekhnologiy - Center for Humanitarian Technologies. Retrieved from: https://gtmarket.ru/laboratory/ basis/3631/3633 [in Russian].

15. Mayo, E. (1933). Human problems of an industrial civilization. New York: Macmillan Co., 194 p. [in English].

16. Roethlisberger, F.J. (1941). Management and Morale. Cambridge, Mass.: Harvard University Press, 194 p. [in English].

17. McGregor, D. (1960). The Human Side of Enterprise. New York: McGraw-Hill, 246 p. [in English].

18. Starobinskiy, E.E. (2000). Nekotorye shtrikhi k kadrovoy politike za rubezhom [Some finishing touches to personnel policy abroad]. Upravlenie personalom - Personnel management, no. 7, pp. 48-51 [in Russian].

19. Guseynova, K.E. (ed.) (2013). Upravlenie chelovecheskimi resursami: uchebnik [Human resource management: textbook]. Baku, 216 p. [in Russian].

\title{
ОГЛЯД ФОРМУВАННЯ Й РОЗВИТКУ СИСТЕМИ УПРАВЛІННЯ ЛЮДСЬКИМ ПОТЕНЦІАЛОМ
}

\author{
Рашад РАФІГЛІ, \\ докторант відділу соціально-економічних проблем рівня життя \\ Інституту економіки Національної академії наук Азербайджану \\ matlabm@yandex.ru \\ orcid.org/0000-0001-5211-8359
}

\begin{abstract}
Метою статті є обтрунтування основних принципів і механізмів підвищення ефективності системи управління персоналом (зокрема, у будівельній галузі).

Методологія та методи. Теоретичною й методологічною основою дослідження $є$ теоретичні та практичні пошуки вітчизняних $і$ зарубіжних економістів і фахівиів у галузі управління, наукові пращі, а також матеріали національних, регіональних та міжнародних наукових конференцій. У дослідженні використовувався порівняльний аналіз різних наукових теорій $і$ концепщій, запропонованих для вдосконалення системи управління.

Результати. У статті розглядаються теоретико-методологічні основи управління будівельною галуззю на основі нетрадичійних, ефективних і сучасних технологічних принципів, визначаються шляхи їх застосування та вдосконалення в системі управління будівельним сектором, що є одним із ключових секторів економіки Азербайджанської Республіки, а також надаються практичні пропозиції щодо вирімення проблем у цій галузі. У статті зазначається, що ефективне використання кадрових ресурсів на підприємстві є різноплановою соиіально-економічною проблемою, яка зачіпає всі сторони життя підприємства. Це пояснюється прагненням керівництва ефективно використовувати залучені кадри для досягнення своїх цілей. У такому разі ефективність має визначатися оптимальним співвіднотенням обсягу кадрових ресурсів, методів їх використання, простору, часу та тривалості взаємодіï.

Висновки. Автор узагальнює питання, підняті в дослідженні, і показує, що підвищення ефективності управління підприємством можливе завдяки систематичному аналізу та застосуванню різних думок, представлених у вітчизняній ізарубіжній спеціалізованій літературі. Зазначається, що для иього керівникам підприємства варто звернути увагу на актуальні питання ефективного використання кадрового потенціалу в майбутньому.
\end{abstract}

Ключові слова: людські ресурси, управління, ефективність, будівельна галузь, соціально-економічні проблеми. 